\title{
COLD TOLERANCE AT THE GERMINATION STAGE OF RICE: METHODS OF EVALUATION AND CHARACTERIZATION OF GENOTYPES
}

\author{
Renata Pereira da Cruz ${ }^{1 *}$; Sandra Cristina Kothe Milach ${ }^{2}$ \\ ${ }^{1}$ IRGA - Divisão de Pesquisa, C.P. 29 - 94930-030 - Cachoeirinha, RS - Brasil. \\ ${ }^{2}$ UFRGS - Depto. de Plantas de Lavoura, C.P. 776 - 91501-970 - Porto Alegre, RS - Brasil. \\ *Corresponding author <rpdacruz@hotmail.com>
}

\begin{abstract}
Rice cold tolerance at the germination stage is important in Rio Grande do Sul (RS) where temperatures below $15^{\circ} \mathrm{C}$ prevent or reduce germination and plant establishment in early sowings. The present study aimed at identifying an adequate method for cold tolerance evaluation of the rice germination stage and at verifying the variability among 24 rice genotypes of different origins. Cold tolerance was evaluated in experiment I, germination under two conditions: $13^{\circ} \mathrm{C}$ for 28 days and $28^{\circ} \mathrm{C}$ for seven days, and in experiment II, germination under $28^{\circ} \mathrm{C}$ for 72 hours, $13^{\circ} \mathrm{C}$ for 96 hours and again $28^{\circ} \mathrm{C}$ for 72 hours. In experiment I measured characteristics were germination index, percentage of seeds with coleoptile length superior to 5 $\mathrm{mm}$ and percentage of reduction in coleoptile length due to cold. In experiment II the measured characteristic was coleoptile regrowth after the cold period. Cold tolerance varied among genotypes studied in both experiments, but only the percentage of reduction in coleoptile length and coleoptile regrowth allowed a better distinction between the tolerant checks and the susceptible one. In general, genotypes belonging to the Japonica subspecies presented higher cold tolerance than Indica, but there was variability within subspecies. The most adequate method of evaluation of cold tolerance is through percentage of reduction in coleoptile length and coleoptile regrowth. Among Japonica genotypes, Quilla 64117 and Diamante presented the highest cold tolerance, and among Indica, cultivars BR-IRGA 410 and IRGA 416 were the most cold tolerant at the germination stage.
\end{abstract}

Key words: Oryza sativa L., low temperature, variability, Indica and Japonica subspecies

\section{TOLERÂNCIA AO FRIO NO ESTÁDIO DE GERMINAÇÃO EM ARROZ: MÉTODOS DE AVALIAÇÃO E CARACTERIZAÇÃO DE GENÓTIPOS}

\begin{abstract}
RESUMO: A tolerância ao frio em arroz no estádio de germinação é importante no Rio Grande do Sul (RS) onde temperaturas abaixo de $15^{\circ} \mathrm{C}$ impedem ou reduzem a germinação e o estabelecimento das plantas em semeaduras precoces. O presente trabalho teve por objetivos identificar uma metodologia adequada para avaliação da tolerância ao frio na germinação em arroz e verificar a variabilidade existente entre 24 genótipos de arroz de diferentes origens. A tolerância ao frio foi avaliada em dois experimentos: experimento I, com germinação sob duas condições: $13^{\circ} \mathrm{C}$ por 28 dias e $28^{\circ} \mathrm{C}$ por sete dias, e experimento II, com germinação a $28^{\circ} \mathrm{C}$ por 72 horas, $13^{\circ} \mathrm{C}$ por 96 horas e novamente a $28^{\circ} \mathrm{C}$ por 72 horas. No experimento I as características medidas foram o índice de germinação, porcentagem de sementes com coleóptilo superior a 5 mm e porcentagem de redução no comprimento do coleóptilo devido ao frio. No experimento II a característica medida foi o recrescimento do coleóptilo após o período de frio. Houve variabilidade para tolerância ao frio entre os genótipos estudados em ambos os experimentos, mas apenas a porcentagem de redução no comprimento do coleóptilo e o recrescimento do mesmo permitiram melhor distinção entre as testemunhas tolerantes e a sensível. Os genótipos da subespécie Japônica apresentaram maior tolerância ao frio que os Indica, no entanto, houve variabilidade dentro das subespécies. O método mais adequado de avaliação da tolerância ao frio é pela porcentagem de redução no comprimento do coleóptilo e recrescimento do mesmo. Entre os genótipos Japônica, Quilla 64117 e Diamante, apresentam maior tolerância ao frio, e entre os Indica, as cultivares BRIRGA 410 e IRGA 416 são as mais tolerantes ao frio no estádio de germinação.
\end{abstract}

Palavras-chave: Oryza sativa L., baixa temperatura, variabilidade, subespécies Indica e Japônica

\section{INTRODUCTION}

In Rio Grande do Sul, Brazil, rice is sown from September to December, according to the region and cli- matic conditions. The sowing time recommended for most medium-cycle cultivars, in the majority of the regions is, however, concentrated from early October to middle November, a period with average temperatures around $15^{\circ} \mathrm{C}$ 
(Oliveira, 1997). Even though temperature does not prevent rice germination, it delays beginning and, consequently, plant emergence. Optimum temperature range for rice germination lies between 20 and $35^{\circ} \mathrm{C}$, and the temperature of $10^{\circ} \mathrm{C}$ is cited as the minimum critical value below which rice does not germinate (Yoshida, 1981b).

Good performance during germination is important to guarantee fast establishment and uniform crop stand (Krishnasamy \& Seshu, 1989). In Rio Grande do Sul, most rice cultivars belong to Indica subspecies, which present slow and not uniform germination under cold temperature, resulting in irregular emergence and low plant population (Souza, 1990). Since management practices can not minimize the problem, genetic breeding for cold tolerance at the germination stage may contribute to a better crop establishment in early sowings.

Selection of cold tolerant genotypes under field conditions is employed in countries such as Korea (Heu \& Bae, 1972) and United States (Carnahan et al., 1972), but is not efficient in Rio Grande do Sul because of the weather instability. Relatively mild, short winter seasons do not present good selection pressure. Rice cold tolerance at the germination stage has been studied under controlled temperature conditions, which allows adjusting intensity and duration, as well as greater precision resulting from the absence of other abiotic and biotic factors that may interfere in field data (Blum, 1988). According to methods of evaluation available in the literature, seeds are submitted to temperatures varying from 10 to $25^{\circ} \mathrm{C}$ for periods of three to thirty five days and characteristics most commonly measured are germination percentage and speed, and coleoptile and radicule length (Maya, 1988; Srinivasulu \& Vergara, 1988; Bertin et al., 1996; Sthapit \& Witcombe, 1998).

These methodologies are important mainly for cold tolerance inheritance studies, in which stress control is fundamental to obtain precise results. For rice, Sthapit \& Witcombe (1998) reported heritability varying from 0.74 to 0.87 for percentage and index of germination, evaluated after submitting seeds to $17^{\circ} \mathrm{C}$ for seven days. Ratho \& Pradhan (1991) identified a male sterile line with high cold tolerance at the germination stage, which has been pointed out as having cytoplasmatic inheritance. For maize, an inheritance study of cold tolerance at the germination stage was also performed under controlled temperature and allowed the identification of aditive-dominant gene action for emergence percentage and initial growth (Revilla et al., 2000).

However, most studies performed under controlled temperature at the rice germination stage are related to the identification of variability and genotype characterization. They were responsible for identifying genotypes of better performance during germination under cold temperatures and, in general, it is known that genotypes belonging to Japonica subspecies are more cold tolerant than Indica (Li et al., 1981; Cruz \& Milach, 1999). Genetic variability for cold tolerance among wild rice lines was also studied (Suh et al., 1997), and three QTLs (quantitative trait loci) related to low temperature germinability were mapped for a population resulting from a cross between a wild and a cultivated line (Suh et al., 1999).

Currently, however, there is a lack of information concerning the behavior of Brazilian rice genotypes in relation to their germination under controlled cold temperatures, and indication of the most adequate methodology for application in breeding programs. In this context, the present study aimed at establishing a methodology of evaluation of cold tolerance at the germination stage under controlled temperature, aiming to identify the most adequate characteristics to be used as evaluation criteria, and to characterize the variability among 24 rice genotypes from the germplasm bank of the Instituto Rio Grandense do Arroz (IRGA) regarding to these characteristics.

\section{MATERIAL AND METHODS}

Twenty four rice genotypes were studied, 12 belonging to Japonica and 12 to Indica subspecies (Table 1). They were chosen because they have different origins and represent a wide range of variability within the rice germplasm. Six of these genotypes are checks (five tolerant and one sensitive) which were included based on observation of their field performance under cold weather. Among the Indica genotypes, six are rice cultivars recommended for planting in RS (BR-IRGA 409, BR-IRGA 410, IRGA 416, IRGA 417, BRS 7 - Taim, and El Paso 144).

Two methods were used to characterize genotypes cold tolerance, described in Experiments I and II. In Experiment I, seeds of 24 rice genotypes were germinated under two conditions: $13^{\circ} \mathrm{C}$ for 28 days (cold) and $28^{\circ} \mathrm{C}$ for seven days (control). For each genotype, seeds from the germplasm bank of IRGA, harvested in the same cropping season, were selected based on size uniformity and absence of spots. They were sterilized with ethanol $70 \%$ for $30 \mathrm{sec}-$ onds and sodium hipoclorite 5\% for 20 minutes, and washed six times with sterile distilled water. Seeds were placed on Petri dishes containing two layers of germination paper, wet with distilled water and $1 \mathrm{~mL}$ of Benomyl solution $2.5 \mathrm{ppm}$ to avoid contamination. The experiment was conducted in a randomized block design with three replications, and the blocks constituted of different shelves in the germination chamber. Each Petri dish contained 20 seeds, and the average of these seeds was used as a replication, amounting to 60 seeds per genotype.

Seeds germinated at $13^{\circ} \mathrm{C}$ had their coleoptile length measured weekly for a period of 28 days and for seeds germinated at $28^{\circ} \mathrm{C}$ this measure was made seven days after the beginning of the experiment. Evaluation of 
Table 1 - Country of origin, subspecies and cold reaction of the rice genotypes used in the study of cold tolerance at the germination stage.

\begin{tabular}{|c|c|c|}
\hline Genotype & Country of origin & Subspecies \\
\hline BR-IRGA 409 & Brazil & Indica \\
\hline BR-IRGA 410 & Brazil & Indica \\
\hline IRGA 416 & Brazil & Indica \\
\hline IRGA 417 & Brazil & Indica \\
\hline BRS 7 - Taim & Brazil & Indica \\
\hline IRGA 284 & Brazil & Indica \\
\hline IRGA 318 & Brazil & Indica \\
\hline IRGA 411 & Brazil & Indica \\
\hline IRGA 411 Liso & Brazil & Indica \\
\hline IRGA 440 & Brazil & Indica \\
\hline El Paso 144 & Brazil & Indica \\
\hline $\operatorname{IR~} 8^{a}$ & Philippines & Indica \\
\hline Frances & Unknown & Japonica \\
\hline El Paso 227 & Uruguay & Japonica \\
\hline INIA Tacuari & Uruguay & Japonica \\
\hline Puntal & Unknown & Japonica \\
\hline IAS $12-9$ Formosa & Formosa Island & Japonica \\
\hline Caloro $^{\mathrm{b}}$ & USA & Japonica \\
\hline Koshihikari ${ }^{\mathrm{b}}$ & Japan & Japonica \\
\hline Quilla $64117^{\text {b }}$ & Chile & Japonica \\
\hline Quilla 66304 b & Chile & Japonica \\
\hline Diamante $^{\mathrm{b}}$ & Chile & Japonica \\
\hline L 202 & USA & Japonica \\
\hline BRS Bojuru & Brazil & Japonica \\
\hline
\end{tabular}

${ }^{\mathrm{a}}$ Genotype used as sensitive check

${ }^{\mathrm{b}}$ Genotypes used as tolerant checks

the genotypes cold tolerance in this experiment was carried out by means of the following characteristics:

- Germination index (GI): $\mathrm{GI}=\left(\mathrm{N}_{14}+\mathrm{N}_{21} / 2\right) / 20 \times 100$, where $\mathrm{N}_{14}=$ number of germinated seeds 14 days after the beginning of the cold treatment; $\mathrm{N}_{21}=$ number of germinated seeds 21 days after the beginning of the cold treatment; 20 being the total number of seeds per genotype per replication. For the GI calculation only the seeds presenting coleoptile and radicule were considered.

- Percentage of seeds with coleoptile superior to $5 \mathrm{~mm}$ (PERCOL5): obtained considering all the germinated seeds 28 days after the beginning of the cold treatment and by verification of the percentage that presented coleoptile length superior to $5 \mathrm{~mm}$, according to the formula:

PERCOL5 $=($ number of seeds with coleoptile $>5 \mathrm{~mm})$ x 100/20.

- Percentage of reduction in coleoptile length (REDCOL): obtained through comparison of average coleoptile length 28 days after germination at $13^{\circ} \mathrm{C}$ (cold treatment) with that obtained 7 days after germination at $28^{\circ} \mathrm{C}$ (control), and calculating the percentage of reduction in coleoptile length by germination under cold temperature, according to the formula:

REDCOL $=[($ col. length under cold temperature $\mathrm{x}$ 100)/ col. length under control] -100 , where coleoptile length is the average of the 20 seeds evaluated per replication per genotype.

In Experiment II, seeds of the 24 rice genotypes were submitted to germination under the following conditions: $28^{\circ} \mathrm{C}$ for 72 hours, $13^{\circ} \mathrm{C}$ for 96 hours and again $28^{\circ} \mathrm{C}$ for 72 hours. This procedure was used to simulate field conditions, where temperature variation is ordinarily observed. The choice and sterilization of the seeds and conduction of the experiment were made according to Experiment I. Coleoptile length was measured in two occasions: after the period of 96 hours at $13^{\circ} \mathrm{C}$ (LENGTH 1) and after the second period of 72 hours at $28^{\circ} \mathrm{C}$ (LENGTH 2). Cold tolerance evaluation was performed through coleoptile regrowth (COLREG; $\mathrm{mm}$ ), which consisted in the difference between the second and the first measurements, or in how much the coleoptile grew under normal temperature after the cold treatment, according to the formula: COLREG $=($ LENGTH 2$)-$ (LENGTH 1), where coleoptile length is the average of the 20 seeds evaluated per replication.

Both experiments were conducted at $13^{\circ} \mathrm{C}$ because this temperature was the one used by Maya (1988) to evaluate cold tolerance at the germination stage of the checks employed in this study. Data from both experiments were submitted to residual analysis to verify normality and variance homogeneity, and to regression analysis to test if data transformation was necessary. The latter indicated the need to transform germination index (Experiment I) through the square root, and coleoptile regrowth (Experiment II) through logarithm. The two other characteristics, percentage of seeds with coleoptile superior to $5 \mathrm{~mm}$ and percentage of reduction in coleoptile length, presented a normal distribution and were not transformed.

Data were, then, submitted to analysis of variance and means comparison by the Tukey test $(P=0.05)$. Relationships among the measured characteristics were established through Pearson's coefficient correlation. All analysis were performed in the Statistical Analysis System (SAS Institute, 2000).

\section{RESULTS AND DISCUSSION}

There was variability for cold tolerance at the germination stage among the genotypes (Table 2). The percentage of reduction in coleoptile length (REDCOL) pre- 
sented the highest coefficient of variation, probably because this characteristic was not transformed and also because it was the only characteristic obtained through comparison of the germination capacity between two contrasting conditions (cold and control), which involved different sets of seeds for a same genotype (treatment).

In relation to the germination index (GI), that expresses the germination speed under cold temperature, IRGA 417 presented values superior to $80 \%$, differing significantly from the others (Figure 1). These results indicate that more seeds of this genotype had germinated 14 and 21 days after the beginning of the experiment. Germination speed is important for crop establishment; however, it does not necessarily hold any relation with the ability of a genotype to elongate coleoptile and radicule under cold temperature. As a matter of fact, for the GI calculation only seeds that presented coleoptile and radicule were considered, independent of their length. Germination speed, and consequently GI, are related to a high seed vigour and this may be the cause of the better performance of IRGA 417 for GI.

Percentage of seeds with coleoptile length greater than $5 \mathrm{~mm}$ (PERCOL5) after 28 days of germination at $13^{\circ} \mathrm{C}$, by its turn, takes into consideration coleoptile length, and despite the wide variation observed among the genotypes, there was no clear separation between genotypes (Figure 2). Fourteen genotypes presented more than $70 \%$ of the seeds with coleoptile length superior to $5 \mathrm{~mm}$, including the tolerant checks (Koshihikari, Quilla 64117, Diamante, Caloro and Quilla 66304), and the cold sensitive IR 8 . This characteristic reflected the coleoptile elongation capacity under cold temperature, and both IR 8 and IRGA 417, superior for GI, also presented high capacity of coleoptile growth, with values greater than $90 \%$ for PERCOL5 (Figure 2). This characteristic is a good criterion to distinguish cold-tolerant from cold-sensitive rice genotypes (Maya, 1988). In fact the five genotypes used as cold tolerance parameters presented high percentage of seeds with coleoptiles longer than $5 \mathrm{~mm}$, the same being true for the sensitive check IR 8 (Figure 2). What demonstrates that this characteristic did not tell apart tolerant and sensitive checks in this case.
Percentage of reduction in coleoptile length by cold (REDCOL) varied from 11 to $68 \%$, and although there was no significant difference, the cold tolerant checks presented lower reductions in coleoptile length due to cold when compared to the sensitive IR 8 (Figure $3)$. All genotypes with reduction smaller than $25 \%$ belonged to Japonica subspecies, with exception of BRIRGA 410, which is an Indica genotype. The lower values for REDCOL were observed for the tolerant checks Diamante, Koshihikari and Quilla 64117 (Figure 3). This characteristic expresses the amount of reduction in genotypes coleoptile length by germination under cold in relation to normal temperature. In this way, the effect of vigour differences among seed lots are minimized.

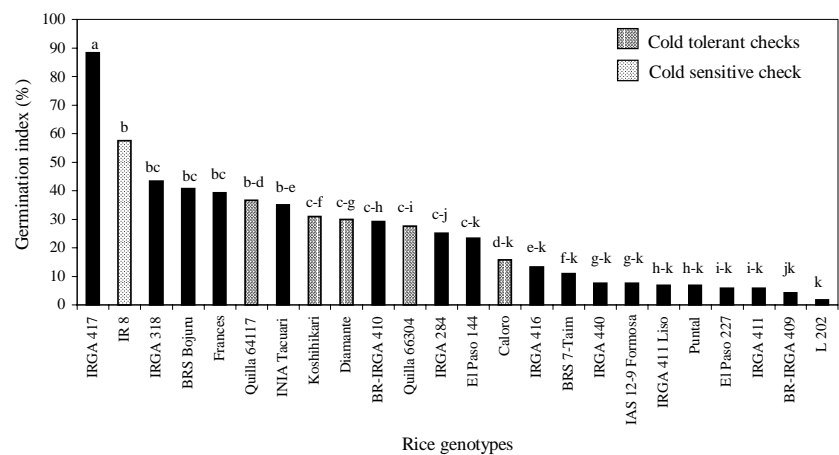

Figure 1 - Germination index for the seeds of 24 rice genotypes submitted to germination at $13^{\circ} \mathrm{C}$ for 28 days, compared by the Tukey test $(\alpha=0.05)$.

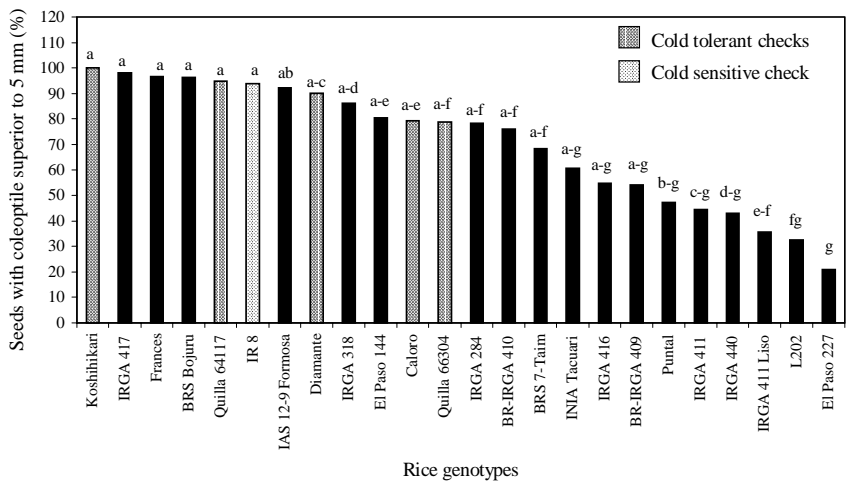

Figure 2 - Percentage of seeds of 24 rice genotypes with coleoptile superior to $5 \mathrm{~mm} 28$ days after germination at $13^{\circ} \mathrm{C}$, compared by the Tukey test $(\alpha=0.05)$.

Table 2 - Mean squares, coefficients of variation and coefficients of determination for the four evaluated characteristics.

\begin{tabular}{lcccc}
\hline & \multicolumn{3}{c}{ Characteristics } \\
\cline { 2 - 5 } Sources of variation & GI & PERCOL5 & REDCOL & COLREG \\
\hline Genotype & $7.98^{* *}$ & $1734.7 * *$ & $776.3^{* *}$ & $0.7 * *$ \\
Blocks & 0.15 & 64.1 & 375.4 & 0.2 \\
Error & 0.35 & 215.3 & 97.7 & 0.1 \\
CV $(\%)$ & 10.4 & 20.7 & 29.0 & 13.0 \\
$\mathrm{R}^{2}$ & 0.92 & 0.80 & 0.81 & 0.80 \\
\hline
\end{tabular}

** Significant at $1 \%$.

$\mathrm{GI}=$ germination index, PERCOL5 = percentage of seeds with coleoptile length greater than $5 \mathrm{~mm}, \mathrm{REDCOL}=$ percentage of reduction in coleoptile length, COLREG $=$ coleoptile regrowth 
Data relative to coleoptile regrowth (COLREG) yielded values varying from $4.3 \mathrm{~mm}$ to $28.3 \mathrm{~mm}$ (Figure 4 ), indicating that the germination process after the cold period was differently affected among genotypes. Three tolerant checks (Diamante, Quilla 66304 and Quilla 64117) formed a group with high coleoptile regrowth, superior to $25 \mathrm{~mm}$. The two other cold tolerant checks, Caloro and Koshihikari, presented intermediate regrowth as well as the sensitive check, IR 8 (Figure 4).

One of the objectives of the present study was to identify a methodology capable of differentiating cold tolerant from cold sensitive genotypes, at the germination stage. Among the characteristics studied, REDCOL was the one that allowed for a better distinction between the tolerant and sensitive checks (Figure 3). Comparison of growth under cold temperature in relation to normal temperature must present a better estimation of a genotype cold answer and this was exactly what was achieved through the percentage of reduction in coleoptile length in this study (Miedema, 1982). In the case of GI and PERCOL5, however, it was not possible to distinguish the tolerant from the sensitive checks. The difficulty in discriminating between the effects relative to cold tempera-

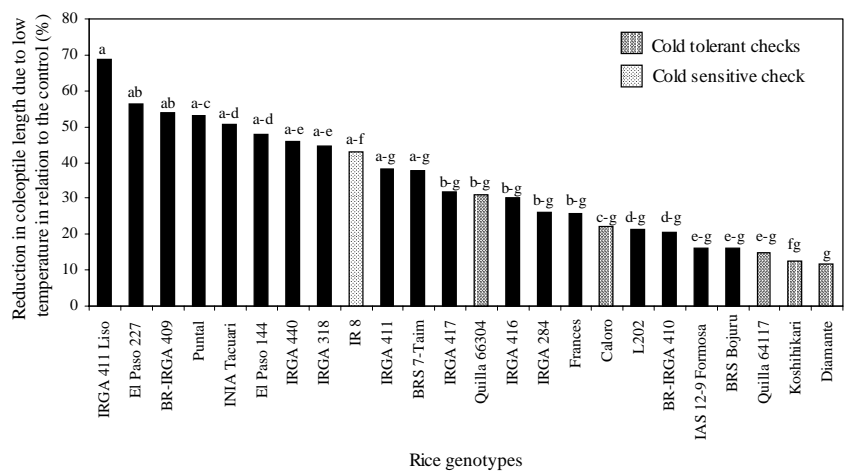

Figure 3 - Percentage of reduction in coleoptile length of 24 rice genotypes, obtained through comparison of their germination under cold temperature $\left(13^{\circ} \mathrm{C}\right.$ for 28 days $)$ with their germination under normal temperature $\left(28^{\circ} \mathrm{C}\right.$ for seven days), compared by the Tukey test $(\alpha=0.05)$. ture and the ones relative to seed vigour, independent of temperature, may have compromised the GI results (Figure 1). In fact, evaluation of germination in more than one temperature is necessary to distinguish cold tolerance from characteristics related to vigour (Massardo et al., 2000). PERCOL5 was also based only on germination under cold temperature, and so it may have the same disadvantages of GI. A strong and highly correlation between these two characteristics was also verified, confirming the similarity of the results (Table 3).

COLREG did also not separate completely the tolerant checks from the sensitive one, but distinguished

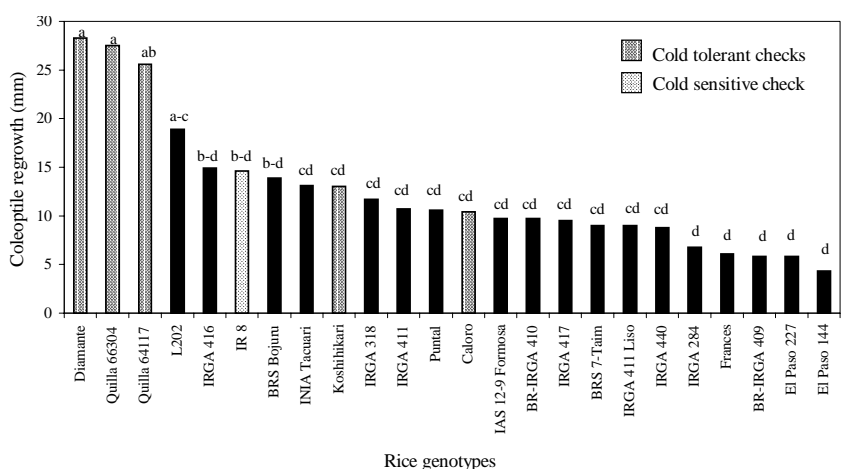

Figure 4 - Coleoptile regrowth $(\mathrm{mm})$ of 24 rice genotypes submitted to germination at $28^{\circ} \mathrm{C}$ for $72 \mathrm{~h}, 13^{\circ} \mathrm{C}$ for $96 \mathrm{~h}$ and $28^{\circ} \mathrm{C}$ for $72 \mathrm{~h}$, compared by the Tukey test $(\alpha=0.05)$.

Table 3 - Correlation coefficients between the characteristics germination index (GI), percentage of seeds with coleoptile greater than $5 \mathrm{~mm}$ (PERCOL5), percentage of reduction in coleoptile length (REDCOL) and coleoptile regrowth (COLREG) evaluated in 24 rice genotypes.

\begin{tabular}{lcccc}
\hline & GI & PERCOL5 & REDCOL & COLREG \\
\hline GI & 1.0 & $0.7 * *$ & $-0.3 * *$ & 0.2 \\
PERCOL5 & & 1.0 & $-0.6 * *$ & 0.2 \\
REDCOL & & & 1.0 & $-0.3 * *$ \\
COLREG & & & & 1.0 \\
\hline
\end{tabular}

**Significant at $1 \%$.

Table 4 - Proposed criteria for characterization of the rice genotypes studied as to their cold tolerance at the germination stage evaluated by means of the percentage of reduction in coleoptile length (REDCOL) and coleoptile regrowth (COLREG).

\begin{tabular}{lcc}
\hline Cold reaction & REDCOL & COLREG \\
\hline \multirow{2}{*}{ Highly tolerant } & $\%$ & equal or greater than 20 \\
Tolerant & equal or less than 25 & between 8 and 20 \\
& equal or less than 25 & equal or greater than 20 \\
Intermediate & between 25 and 50 & between 8 and 20 \\
& between 25 and 50 & equal or less than 8 \\
Sensitive & equal or less than 25 & equal or greater than 20 \\
& equal or greater than 50 & between 8 and 20 \\
Highly sensitive & equal or greater than 50 & equal or less than 8 \\
\hline
\end{tabular}

Sci. Agric. (Piracicaba, Braz.), v.61, n.1, p.1-8, Jan./Fev. 2004 
two tolerant checks from the sensitive IR 8 (Figure 4). In this character, only ten days were enough to obtain the results, and the temperature variation allowed for simulating what happens under field conditions, where periods of cold temperature are inserted between periods of high temperature. In addition, the initial temperature of $28^{\circ} \mathrm{C}$ aimed at minimizing intrinsic differences of vigour among the genotypes, providing ideal germination conditions to all seeds. Therefore, differences in COLREG among genotypes may be an indicative of a distinct capacity of recovery of the germination process after a cold period, and of different degrees of cold tolerance.

Both REDCOL and COLREG seem to be the most adequate characteristics to be used to evaluate cold tolerance during the germination period in rice. Correlation between them was negative as expected (Table 3), proving that a greater coleoptile regrowth was accompanied by a lower reduction in coleoptile length due to cold temperature. However, this correlation was low, indicating that some genotypes considered tolerant based on a bigger COLREG, may be considered sensitive based on their REDCOL, and vice-versa. It is thus worthy discussing whether the low correlation between the REDCOL and COLREG indicates either they are related to different aspects of cold tolerance or not.

Germination is divided into three phases: imbibition, activation and post-germination growth (Yoshida, 1981a). The largest effects of cold temperature during germination seem to be associated to the imbibition phase, considered the most sensitive (Simon apud Blum, 1988). Cold temperature during this phase leads to increasing escape of solutes from the seeds, such as aminoacids and carbohydrates, which has been attributed to the incomplete plasma membrane of the dry seed and to the disturbance caused on its reconstruction during imbibition phase by cold temperature.

Cellular membrane is considered the main target for cold damage and the primary cause of other metabolic disturbances observed within cells (Lyons, 1973). The reason for this is the phase transition that takes place in the plasma membrane under cold temperature, which changes from a liquid-crystallin state to a solid-gel state, leading to physical contraction and opening of channels that increase its permeability. Differences in the composition of the lipid layer were pointed out as responsible for the greater tolerance to the phase transition under cold temperature, in such a way that the greater the lipid insaturation degree, the larger the cold tolerance, because the phase transition would occur at a lower temperature (Murata \& Yamaya, 1984).

Differences in lipid composition were observed between cold tolerant and sensitive rice genotypes, with the first ones presenting a larger proportion of insaturate fatty acids (Majumder et al., 1989). Similarly, Bertin (1998) verified alterations in the fatty acid composition of the lipid layer in rice somaclones presenting higher cold tolerance than the original genotypes. It may thus be speculated that the differential behavior of some genotypes when evaluated through REDCOL and COLREG was related to the imbibition phase of the seeds that occurred at $13^{\circ} \mathrm{C}$ in the first and at $28^{\circ} \mathrm{C}$ in the second.

In spite of the imbibition being considered the most sensitive phase, Yoshida (1981a) reports that the greatest influence of temperature on germination occurs in the subsequent phases of activation and growth of coleoptile and radicule. The reduction in coleoptile growth during these phases may be attributed to the direct effect of cold temperature on cellular elongation and division, or to its indirect effect leading to a metabolic unbalance (Lyons, 1973). These phases must have been affected in both characteristics, but, while in REDCOL cold temperature was constant during all 28 days of germination, in COLREG it lasted for only four days. Once again, each characteristic evaluated different aspects, the first case being the capacity of coleoptile to grow under permanent cold and; in the latter, the capacity of growth recovery under normal temperature after cold stress.

Physiological mechanisms involved with cold tolerance at the vegetative period are better understood. Among the many processes that have been studied and published, the regulating role of kinases dependent on calcium and activated by cold temperature exposition (Saijo et al., 2000; Martín \& Busconi, 2001); the involvement of abscisic acid as a signalling molecule (Lee et al., 1995); and the levels of activation of the enzymes associated to oxidative stress such as ascorbate peroxidase (Sato et al., 2001), catalase and glutathione reductase (Kang \& Saltveit, 2002) may be cited. Despite the lack of knowledge regarding the germination period of rice, the existence of different physiological mechanisms involved with cold tolerance at the vegetative period is an indication that along the germination phases, different processes may also be affected, implying in different tolerance mechanisms. For instance, Massardo et al. (2000) studied two oat cultivars, one tolerant and another sensitive, in relation to the physiological aspects involved during germination under cold temperature $\left(3^{\circ} \mathrm{C}\right)$, and demonstrated that higher metabolic rates and less oxidative damage were the answers of the tolerant genotype to cold temperature during germination.

Under these premises, the low correlation between REDCOL and COLREG may be attributed to the fact that they are associated to different cold tolerance mechanisms at the germination period, and yield complementary results in cold tolerance evaluation, that is, genotype characterization for cold tolerance at the germination stage should consider the results of both characteristics simultaneously. Based on the extent of variation obtained for REDCOL and COLREG, and on the perfor- 
mance of the tolerant checks in this study, a criterion for characterization of the genotypes, in relation to their cold reaction at the germination stage, is proposed (Table 4). It comprises five classes of cold reaction that are determined by nine different combinations of values for REDCOL and COLREG. Considering this classification, attention shall be drawn to genotypes Quilla 64117 and Diamante, once they are highly cold tolerant at the germination stage (Figures 3 and 4). It was also observed that the genotype IR 8, though used as a sensitive check, was not inferior to the other genotypes, showing an intermediate or even superior behavior to many of them (Figures 3 and 4). Indica genotypes generally need higher temperatures to germinate than Japonica, and the same is true for photoperiod sensitive and insensitive genotypes, indicating a higher sensitivity to cold temperature of Indica and photoperiod sensitive genotypes (Oka apud Takahashi, 1984). This might be an explanation for the intermediate behavior of IR 8 , which is a photoperiod insensitive genotype.

The variability among the rice genotypes was expected because of their different origins and the two subspecies they belong to. However, variability for cold tolerance was also observed within each subspecies. The availability of cold tolerance sources within the Indica subspecies is interesting for breeding cold tolerant genotypes to be cultivated in Rio Grande do Sul, since it allows them to be used as genitors in crosses, preventing the sterility problems that result from Indica $\mathrm{x}$ Japonica crosses (Kubo \& Yoshimura, 1999; Kubo et al., 2000) as well as the transfer of undesirable characters from the Japonica genotypes to the adapted Indica ones. In this sense, the genotype BR-IRGA 410 may be considered a possible cold tolerance source among the Indica genotypes studied, once the values obtained for REDCOL and COLREG (Figures 3 and 4) allow to classify it as a tolerant genotype (Table 4).

In the breeding process for cold tolerance at the germination period, evaluation of the percentage of reduction in coleoptile length and of coleoptile regrowth is, then, indicated for the identification of cold tolerant genotypes, to be used as genitors. Percentage of reduction in coleoptile length, however, is not viable as a cold tolerance selection criterion in segregant populations because it demands exposition of the same genotype to two different temperature situations: cold and control. But it may be used for the identification of the general and specific combining abilities of genitors by means of $F_{1}$ generation evaluation. Coleoptile regrowth, by its turn, does not have any use limitations and may be used as a selection criterion in any segregant generation, with the advantage of being a method that involves little space and time for evaluating a high number of plants simultaneously. Recommendation of which generation to select, however, depends on the determination of the inheritance and heritability of the characteristic in cold tolerant genotypes.

\section{REFERENCES}

BERTIN, P. Somaclonal variation and chilling tolerance improvement in rice: changes in fatty acid composition. Plant Growth Regulation, v.24, p.31-41, 1998.

BERTIN, P.; KINET, J.M.; BOUHARMONT, J. Evaluation of chilling sensitivity in different rice varieties. Relationship between screening procedures applied during germination and vegetative growth. Euphytica, v.89, p.201-210, 1996.

BLUM, A. Plant breeding for stress environments. Boca Raton: CRC, 1988. cap.5, p.99-132: Cold Resistence.

CARNAHAN, H.L.; ERICKSON, J.R.; MASTENBROEK, J.J. Tolerance of rice to cool temperatures - USA. In: INTERNATIONAL RICE RESEARCH INSTITUTE. Rice breeding. Los Baños: IRRI, 1972. p.535-540.

CRUZ, R.P. da; MILACH, S.C.K. Variabilidade genética em arroz irrigado (Oryza sativa L.) para tolerância ao frio durante a germinação. Genetics and Molecular Biology, v.22, p.699, 1999. Supplement.

HEU, M.H.; BAE, S.H. Selection for lines of rice tolerant to low temperature in Korea. In: INTERNATIONAL RICE RESEARCH INSTITUTE. Rice breeding. Los Baños: IRRI, 1972. p.533-534.

KANG, H.M.; SALTVEIT, M.E. Antioxidant enzymes and DPPH-radical scavenging activity in chilled and heat-shocked rice (Oryza sativa L.) seedlings radicles. Journal of Agricultural and Food Chemistry, v.50, p.513-518, 2002.

KRISHNASAMY, V.; SESHU, D.V. Seed germination rate and associated characters in rice. Crop Science, v.29, p.904-908, 1989.

KUBO, T.; YOSHIMURA, A. Complementary genes causing $\mathrm{F}_{2}$ sterility in Japonica/Indica cross of rice. Rice Genetics Newsletter, v.16, p.68-70, 1999.

KUBO, T.; EGUCHI, M.; YOSHIMURA, A. A new gene for $\mathrm{F}_{1}$ pollen sterility in Japonica/Indica cross of rice. Rice Genetics Newsletter, v.17, p.63-64, 2000.

LEE, T.M.; LUR, H.S.; CHU, C. Abscisic acid and putrescine accumulation in chilling-tolerant rice cultivars. Crop Science, v.35, p.502-508, 1995.

LI, T.G.; VISPERAS, R.M.; VERGARA, B.S. Correlation of cold tolerance at different growth stages in rice. Acta Botanica Sinica, v.23, p.203207, 1981 .

LYONS, J.M. Chilling injury in plants. Annual Review of Plant Physiology, v.24, p.445-466, 1973.

MAJUMDER, M.K.; SESHU, D.V.; SHENOY, V.V. Implication of fatty acids and seed dormancy in a new screening procedure for cold tolerance in rice. Crop Science, v.29, p.1298-1304, 1989.

MARTÍN, M.L.; BUSCONI, L. A rice membrane-bound calcium-dependent protein kinase is activated in response to low temperature. Plant Physiology, v.125, p.1442-1449, 2001.

MASSARDO, F.; CORCUERA, L.; ALBERDI, M. Embryo physiological responses to cold by two cultivars of oat during germination. Crop Science, v.40, p.1694-1701, 2000.

MAYA, O.I.M. Identificacion de metodologias para la evaluacion de tolerancia a temperaturas bajas en arroz (Oryza sativa L.) Palmira: Universidade Nacional de Colombia / Facultad de Ciencias Agropecuarias, 1988. 123p. (Monografia - Graduação).

MIEDEMA, P. The effects of low temperature on Zea mays. Advances in Agronomy, v.35, p.93-128, 1982.

MURATA, N.; YAMAYA, J. Temperature-dependent phase behaviour of phosphatidylglycerol from chilling-sensitive and chilling resistant plants. Plant Physiology, v.74, p.1016-1024, 1984.

OLIVEIRA, H.T. de. Climatologia das temperaturas mínimas e probabilidade de ocorrência de geada no Estado do Rio Grande do Sul. Porto Alegre: UFRGS, 1997. 81p. (Dissertação - Mestrado).

RATHO, S.N.; PRADHAN, S.B. Cytosplasmically controlled cold tolerance in a cytoplasmic-genetic male sterile line of rice. Euphytica, v.58, p.241244, 1991.

REVILLA, P.; MALVAR, R.A.; CARTEA, M.E.; BUTRÓN, A.; ORDÁS, A. Inheritance of cold tolerance at emergence and during early season growth in maize. Crop Science, v.40, p.1579-1585, 2000.

SAIJO, Y.; HATA, S.; IZUI, K. Over-expression of a single $\mathrm{Ca}^{2+}$ dependent protein kinase confers both cold and salt/drought tolerance on rice plants. Plant Journal, v.23, p.319-327, 2000. 
SAS INSTITUTE. System for information. Versão 8.0. Cary: SAS Institute, 2000.

SATO, Y.; MURAKAMI, T.; FUNATSUKI, H.; MATSUBA, S.; SARUYAMA, H. Heat shock-mediated APX gene expression and protection against chilling injury in rice seedlings. Journal of Experimental Botany, v.52, p.145-151, 2001.

SOUZA, P.R. Alguns aspectos da influência do clima temperado sobre a cultura do arroz irrigado, no sul do Brasil. Lavoura Arrozeira, v.43, p.9-11, 1990.

SRINIVASULU, K.; VERGARA, B.S. Screening of upland and short duration rice varieties for cold tolerance at seedling emergence stage. Oryza, v.25, p.87-90, 1988.

STHAPIT, B.R.; WITCOMBE, J.R. Inheritance of tolerance to chilling stress in rice during germination and plumule greening. Crop Science, v.38, p.660-665, 1998.

SUH, H.S.; SATO, Y.I.; MORISHIMA, H. Genetic characterization of weedy rice (Oryza sativa L.) based on morpho-physiology, isozymes and RAPD markers. Theoretical and Applied Genetics, v.94, p.316-321, 1997.
SUH, J.P.; AHN, S.N.; MOON, H.P.; SUH, H.S. QTL analysis of low temperature germinability in a Korean weedy rice (Oryza sativa $\mathrm{L}$.) Rice Genetics Newsletter, v.16, p.53-55, 1999.

TAKAHASHI, N. Differentiation of ecotypes in Oryza sativa L. In: TAKAHASHI, N.; TSUNODA, S. (Ed.) Biology of rice. Tokyo: Japan Scientific Societies Press, 1984. p.31-67.

YOSHIDA, S. Fundamentals of rice crop science. Los Baños: IRRI, 1981a. cap.1, p.1-63: Growth and development of the rice plant.

YOSHIDA, S. Fundamentals of rice crop science. Los Baños: IRRI, 1981b. cap.2, p.65-110: Climatic environment and its influence.

Received January 24, 2003

Accepted November 10, 2003 